Volume 16, Number 1, Juni 2019

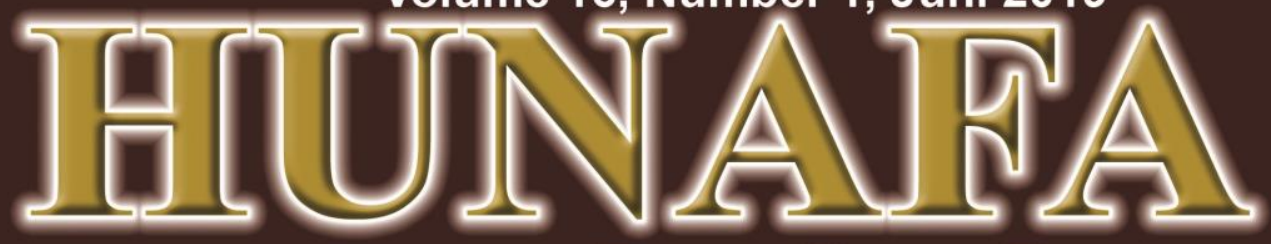

Jurimal Stradial Islamilka

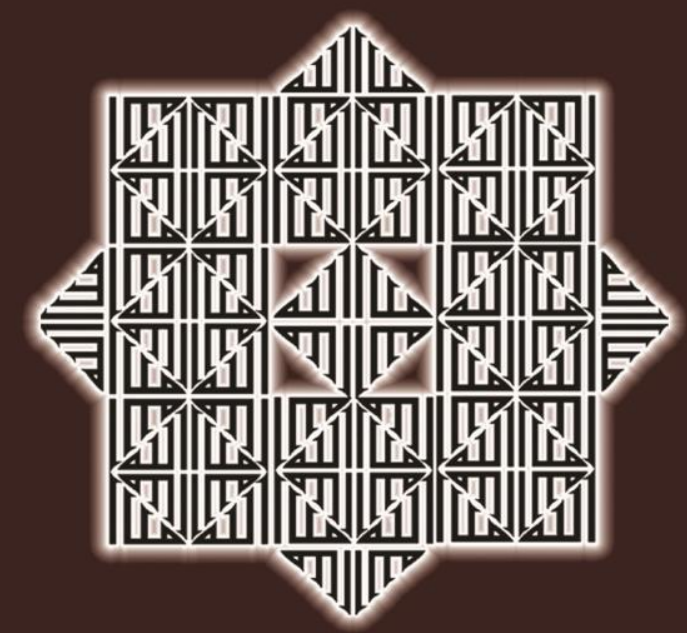

ALKHAIRAAT POLITICAL CHARISMA Syamsuri

IRAN REVOLUTION, ECONOMIC STRUGGLE AND INDEPENDENCE UNDER PRESSURE Meirizon Alizar Ali

\author{
MARKETING PERFORMANCE DETERMINANT \\ OF HALAL PRODUCTS IN INDONESIA \\ Confirmatory Factor Analysis Approach \\ Aan Nasrullah
}

State lnstitute for lsiamic Studies (ILAIN) Palu central Sulawesi

\begin{tabular}{|c|c|c|c|c|c|}
\hline $\begin{array}{c}\text { HUNAFA } \\
\text { JSI }\end{array}$ & $\begin{array}{c}\text { Volume } \\
16\end{array}$ & $\begin{array}{c}\text { Number } \\
1\end{array}$ & $\begin{array}{c}\text { Page } \\
1-153\end{array}$ & $\begin{array}{c}\text { Palu } \\
\text { Juni } 2019\end{array}$ & $\begin{array}{c}\text { ISSN } \\
\text { 141-125X }\end{array}$ \\
\hline
\end{tabular}




\section{HUNAFA}

Jurnal Studia Islamika

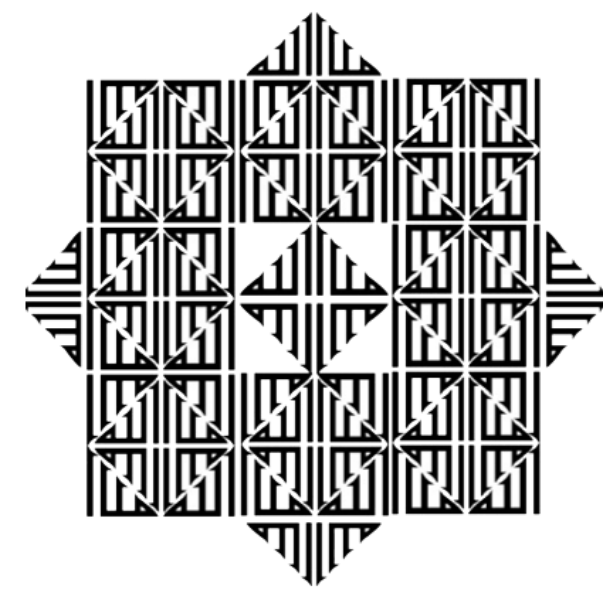

Published by:

State Islamic Institute (IAIN) Palu

Central Sulawesi 


\section{HUNAFA}

Jurnal Studia Islamika

HUNAFA: Jurnal Studia Islamika is an Islamic studies journal dedicated to publishing scholarly articles on all aspects of Islam and the Muslim peoples and religious studies. Available in print and online and published twice a year, the journal aims to become one of the leading platforms in Indonesia for new findings and discussions of all fields of Islamic studies. This journal invites scholars, researchers, and students to contribute the result of their studies and researches in the areas related to Islam and Muslim society which covers textual and fieldwork investigation with various perspectives of law, education, quranic studies, economiy, philosophy, mysticism, theology, sociology, and others.

\section{CAll rights reserved}

No part of this publication may be reproduced in any form without written permission from HUNAFA, to whom all requests to reproduce copyright material should be directed. HUNAFA grants authorization for individuals to photocopy copyright material for private research use. This authorization does not extend to any other kind of copying, by any means, in any form, and for any purposes other than private research.

\section{Open Acces Journal Information}

The journal provides immediate open access to its content on the principle that making research freely available to the public supports a greater global exchange of knowledge. The journal offers full access contents at http://jurnalhunafa.org.

\section{Printed Journal Subscription Information}

Institution Rp 100.000,00 /issue; Rp 1.100.000,00/year

Individual: Rp. 60.000,00/issue; Rp. 600.000,00/year

Outside Indonesia (individual or institution) \$60/month; \$600/year

For detail information of printed journal subscription, feel free to contact the journal manager at hunafajournal@gmail.com.

\section{Mailing Address}

HUNAFA: Jurnals Studia Islamika

Lembaga Penelitian dan Pengabdian Masyarakat (LP2M) IAIN Palu 
Jl. Diponegoro No. 23 Palu, Sulawesi Tengah 94221 Indonesia

Phone: +62-451-460798; Fax: +62-451-460165

E-mail: jurnalhunafa@yahoo.com; hunafajournal@gmail.com

Website: www.jurnalhunafa.org

HUNAFA

Jurnal Studia Islamika

\section{EDITOR-IN-CHIEF}

Nurdin, Institut Agama Islam Negeri Palu, Indonesia

\section{EDITORIAL BOARD}

Sagaf S. Pettalongi, Institut Agama Islam Negeri Palu, Indonesia

Rusli, Institut Agama Islam Negeri Palu, Indonesia

Tulus Suryanto, Universitas Islam Negeri Raden Intan Lampung, Indonesia

Ade Yeti Nuryantini, Universitas Islam Negeri Sunan Gunung Djati, Indonesia

Toto Suharto, Institut Agama Islam Negeri Sukoharjo, Indonesia

Reza Fahmi, Universitas Islam Negeri Imam Bonjol Padang, Indonesia

Mohamad Abdalla, University of South Australia, Australia

Cucuk Wawan Budiyanto, Universitas Sebelas Maret, Indonesia

Kevin W. Fogg, University of Oxford, United Kingdom

Al Makin, Universitas Islam Negeri Sunan Kalijaga Yogyakarta, Indonesia

Miftachul Huda, Universiti Teknologi Malaysia, Malaysia

Hendri Tanjung, Ibn Khaldun University Bogor, Indonesia

Muhammed Modassir Ali, Hamad bin Khalifa Universty, Qatar

Hamid Fahmi Zarkasyi, Universitas Darussalam Gontor, Indonesia 


\section{MANAGING EDITOR}

Mohammad Nur Ahsan, Institut Agama Islam Negeri Palu, Indonesia

\section{COVER DESIGN}

Lukman Latif 


\section{HUNAFA}

\section{Contents}

Editorial

vi-vii

AL-KHAIRAAT POLITICAL KHARISMA

Syamsuri

BANGRENG AS A MEANS OF SPREADING ISLAM

Melyan Sofian, Cece Sobarna, Reiza D. Deinaputra, Deni Hermawan

FOREIGN LANGUAGE TEACHING AND INFORMATION COMMUNICATION TECHNOLOGY: IS THERE OPPORTUNITY FOR QURANIC LANGUAGE TEACHERS?

Nuril Mufidah, Abduganiy Abimbola Abdussalam, Aliy Abdulwahid Adebisi

IRAN REVOLUTION, ECONOMIC STRUGGLE AND INDEPENDENCE UNDER THE PRESSURE

Meirozon AlizarAli 
KAISA METHOD IN INTELLIGENCE MULTIPLE PERSPECTIVE $\quad 78-87$

Umi Salamah

MAHRAM IMPLICATIONS IN WOMEN'S TRAVEL

$88-110$

Maulidah Tri Utami

MARKETING PERFORMANCE DETERMINANT

OF HALAL PRODUCTS IN INDONESIA:

Confirmatory Factor Analysis Approach

Aan Nasrullah

RELATIONS BETWEEN MOSQUE AND

$142-153$

SOCIAL HISTORY OF ISLAMIC EDUCATION

Anna Triayudha, Rateh Ninik Pramitasary, Hermansyah Akbar Anas, Choirul Mahfud 


\section{Editorial Preface}

Nurdin Nurdin, Institut Agama Islam Negeri (IAIN) Palu

This issue (Vol. 16 issues 1) of Hunafa: Jurnal Studia Islamika offers eight articles covering topics of Islamic studies. Various issues relating to Islamic studies are presented interestingly to contribute to the body of knowledge and practices. Academia and practitioners in Islamic studies may gain insight from reading these articles.

The first article is titled "Al-Khairaat Political Kharisma" by Syamsuri Syamsuri from Department of Dakwah, Faculty of Ushuluddin, Adab, and Dakwah, Institut Agama Islam Negeri Palu. This paper discusses the roles of Al-Khairaat in politics arena within local and national level. Several political parties have come to the Alkhairaat organization to recruit political cadres in the face of general election events.Alkahiraat's political charisma in the frame of political communication includes the participation, consolidation, and partnership of Alkhairaat politicians who spread in various political parties to win the election contestation.

The second article in the issue is titled "Bangreng as a Means of Spreading Islam" by Maylan Sofian, Cece Sobarna, Reiza D. Dienaputra, and Deni Hermawan from STKIP Sebelas April Sumedang. This paper describe Bangreng culture which was originally an example used by the Sumedang community as a medium to express gratitude for everything that Allah SWT gave to humans. But the function of art as a ritual began to shift into art as entertainment. This Bangreng art is an art that is very interesting to study because there are only a few different functions. This change does not change the name of the show. With this description, it needs to be isolated, that is, the community does not lose identity. The aim is that the public knows the function of the nation in the spread of Islam.

The third article is titled "Determinants of Halal Product Marketing Performance In Indonesia: Confirmatory Factor Analysis Approach" by Aan Nasrullah. This paper discussed the five variables that contribute to halal product marketing which are product competition, HR marketing performance, infrastructure, amount of distribution cost, and market competition.

The fourth article is titled "Foreign Language Teaching and Information Communication Technology: Is There Opportunity for Quranic Language Teachers?"by Nuril Mufidah, Abdulganiy Abimbola Abdussalam, Aliy Abdulwahid Adebisi from UIN Maulana Malik Ibrahim Malang and University of Ilorin, Ilorin, Nigeria. The article discuses the use of ICT in learning of Arabic. The subjects of the study were students of Arabic Language Education at UIN Maulana Malik Ibrahim Malang Indonesia 2018 academic year and students and Department of Arabic, Faculty of Arts University of Ilorin, Nigeria. The findings of the research are that ICT if adequately harnessed and utilized will go a long way in enhancing the quality of teaching of Arabic, as it was established to teaching other languages of the world.

The fifth article is by Meirizon Alizar Ali dari UIN Imam Bonjol. The article is titled "Iran Revolution, Economic Struggle and Independence under the Pressure" The article discusses 
Iran economy situation after experiencing various kinds of changes in economic policy and facing various kinds of situations Iran succeeded in developing the economy without changing the basics of Islamic shari'ah principles and revolution.

The sixth article is titled "Kaisa Method in Intelligence Multiple Perspective" by Umi Salamah from PGMI, STAI Ma'had 'Aly Al-Hikam, Malang. The article analyzed memorizing the Qur'an using the Kaisa method in the perspective of multiple intelligence. The Kaisa method is a way of memorizing the Qur'an which is oriented to memorization and understanding of the verses of the Qur'an along with their meanings through movements or kinesthetic which are adapted to the meaning of each verse so as to make it easy to understand and remember every verse of the Qur'an given.

The seventh article is titled "Mahram Implications in Women's Travel" by Maulidah Tri Utami from Faculty UshuluddinAdab and Humaniora, IAIN Salatiga. The article discusses mahram as well as a culture of the manner in which a woman is going out of her home or is drawn. From the various resources available this article determine when a woman can compete without mahram.that is how Islam respects and cares for a woman so much that it also notices when a woman is about to travel. Not just one woman, but all Muslim have a rule if a Muslim is to compete for a long time. So, when to reply a Muslim must meet or finish what he needs before taking a sauna.

The last article is titled "Relations Between Mosque And Social History Of Islamic Education" by Choirul Mahfud Anna Triayudha, Rateh Ninik Pramitasary, and Hermansyah Akbar Anas from Institut Teknologi Sepuluh Nopember, Surabaya and Pascasarjana Universitas Muhammadiyah Sidoarjo. The article describe the early period of Islamic education, the Prophet provided exemplary by building and empowering mosques. The example of the Prophet continued with the Caliphs afterwards until the present era. The mosque was built by the Prophet from the Al Haram mosque located in Makkah, Quba Mosque located in Quba, Nabawi mosque located in Medina and so on. The role and function of the mosque at that time was as a place of prayer, a place of prayer, a place for discussion or deliberation, a meeting place to develop a war strategy and others related to the problems and needs of Muslims. From time to time, the role or function of the mosque has changed slightly. In essence, mosques are currently influencing the development of the social history of Islamic education in Indonesia.

I hope the articles presented in this issue add further empirical evidence to the growing body of research that examines various fields from Islam perspectives. The articles could trigger other research to study other field of study with Islam perspectives Islamic institutions in Indonesia.

Nurdin Nurdin

Editor-in-Chief

HUNAFA: Jurnal Studia Islamika

XVI, 1 


\title{
BANGRENG AS A MEANS OF SPREADING ISLAM
}

\author{
Maylan Sofian ${ }^{1}$, Cece Sobarna ${ }^{2}$, Reiza D. Dienaputra ${ }^{3}$, and Deni Hermawan ${ }^{4}$
}

\author{
${ }^{1}$ STKIP Sebelas April, Sumedang, maylansofian55@gmail.com \\ ${ }^{2}$ STKIP Sebelas April, Sumedang \\ ${ }^{3}$ STKIP Sebelas April, Sumedang \\ ${ }^{4}$ STKIP Sebelas April, Sumedang
}

\begin{abstract}
Bangreng was originally an example used by the Sumedang community as a medium to express gratitude for everything that Allah SWT gave to humans. But the function of art as a ritual began to shift into art as entertainment. This Bangreng art is an art that is very interesting to study because there are only a few different functions. This change does not change the name of the show. With this description, it needs to be isolated, that is, the community does not lose identity. The aim is that the public knows the function of the nation in the spread of Islam. The method used in this study is qualitative research design. The Bangreng as the object of the research. From this research, it is expected that it can show the Bangreng as a means of Islamic preaching medium.
\end{abstract}

Keywords: Bangreng, definition of dissemination, Islam

\begin{abstract}
Abstrak. Bangreng pada awalnya adalah sebuah perwujudan yang digunakan oleh komunitas Sumedang sebagai media untuk menyatakan terima kasih atas segala yang diberikan Allah SWT kepada manusia. Namun fungsi seni sebagai ritual mulai bergeser menjadi seni sebagai hiburan. Seni Bangreng ini adalah seni yang sangat menarik untuk dipelajari karena ada beberapa fungsi dari Bangreng yang beragam. Perubahan ini tidak mengubah nama pertunjukan. Dengan uraian ini, perlu digaris bawahi, yakni masyarakat tidak kehilangan identitas. Tujuannya agar publik mengetahui fungsi bangsa dalam penyebaran Islam. Metode yang digunakan dalam penelitian ini adalah desain penelitian kualitatif. Bangreng sebagai objek penelitian. Dari penelitian ini, diharapkan dapat menunjukkan Bangreng sebagai sarana media dakwah Islam.
\end{abstract}

Kata Kunci: Bangreng, definisi diseminasi, Islam. 
DOI: $10.24239 /$ jsi.v16i1.503.20-33

\section{Introduction}

Bangreng art is an art that starts from the art of flying. Flying is an art that is related to ceremonial rituals and then at the ceremony. A musical instrument that uses three pieces of bamboo instruments; Gemyung, Kendang, and Goong. The lyrics of the song are about religious songs, such as "LaillahaIlallah Muhamad Arrosulallah" performed repeatedly. Men carried out the singer at the time of the flying incident. With a simple music motif, it is always repeated. In this round, only the event was held. This inheritance system in the art of flying, cannot be done fairly inherited from generation to generation. Even today, the art of flying at the beginning of Bangreng is still being treated and well maintained. But there is a part of the community that does not know the function of Bangreng as a means of worship. Modern society only mentions it as art.

Many rules occur in flying shows. This is also one of the factors that lack the development of flying art or now this Bangreng art.

\section{Theoretical review}

Research ideas must have relevant information. This can make it easier for researchers to carry out the process and to avoid duplication of research, but it is also made possible by previous studies. So far, studies relating to the art of Bangreng is positively responded by people.

A literature study was conducted to trace sources related to previous studies and no research was found that was directly related to the art of North Sumatra. Based on the results of the search, data were obtained in the form of several writings that were discussed about Bangreng art. There is no theses and dissertations focusing on Bangreng, while previous research related to Bangreng art was only a research report. Therefore the author find it difficult to find data relating to the data that is carried out. The data that is close to the titles of research that will be carried out as follows.

First, the dissertation of Endang Caturwati entitled Sinden - Dancer above and beyond the Stage: Socio-Cultural Life for Penen Klining Jaipongan in Subang Region, West 
Java. ${ }^{1}$ This research began in the 1980s known as jaipongan, the emergence of jaipongan as if reconstructing a long-extinct feature that had happened. In the early years of the 1950s to 1980s who avoided erotic movements, wiggled the hips. Despite the discussion of Islamic ritual, the study shows no Islamic ritual in the art show.

Second, Een Herdiani's dissertation entitled Dinamika Rakyat Dance in Priangan, ${ }^{2}$ This dissertation is motivated by the unique diversity of people's cultural wealth in Priangan. From the peculiarities of the folk culture, there are people in it who include things that are not-not-infinite by the people. Dance writing is not an easy thing, but it can be done. Folk dance used to do life everyday in Sunda. Some of these things are in the background. In the chapter on the contents of this dissertation, there are some will be discussed first, explaining how the life of folk dance in the Priangan community from its birth embryo. Beginning with the definition of dance from various sources, and expressing art, art that has ritual dance movements such as tayub, tarawangsa, etc. Also explained about the art of ronggeng as a folk art that lives in the Priangan community. Also discussed about naming ronggeng directly in art such as ronggeng gunung, ronggeng amen, ronggeng tayub, and ronggeng kaler. In the second part describes the ronggeng as a popular folk art in the Priangan community whose birth is thought to be a ritual event inherent in the life of the priangan community. The shift in the function of art from ritual to entertainment influences the form and procedure of serving. Likewise with the imaging of the artist and of the art form itself. In this chapter explains the origin of Ronggeng from evidence such as from Pantun, Bogor. In this section also discusses the similarity of the term ronggeng in some areas such as Central Java and East Java known as ledhek, lengger, gandrung; in Bali jogged and gandrung; at Madura sindur; in Bugis, and Makassar Pajogeq; in Sumatra Makyong; on the outskirts of Jakarta Cokek. Ronggeng is an interesting figure in the life of the world of folk art cannot be separated from hereditary stories that are still believed to be true by most Sundanese people. In this section explain many of the myths that occur related to ronggeng. Explain about the existence of ronggeng in Mt. Sanggabuana, Karawang. The third part discusses the transformation of the art of ronggeng into ketuktilu which emerges from various aspects, from the

\footnotetext{
${ }^{1}$ Endang Caturwati. "Sinden - Penari di atas dan di luar Panggung :Kehidupan Sosial Sosial Budaya para Sinden-Penari kliningan Jaipongan di Wilayah Subang Jawa Barat." (Disertasi, UGM, 2005).

${ }^{2}$ Een Herdiani. Dinamika Tari Rakyat di Priangan. (Disertasi, Universitas Padjadjaran, 2012)
} 
beginning tap tilu as a ritual art. The art presented in a ceremony is not identical to the ceremony itself but its presence as a medium. In the tilu tap presentation there are elements that are quite prominent, namely spontaneity, vulgarity, and humorous both motion and song lyrics. Tap tilu is better known by the public as an art that functions as entertainment or association. The fourth section examines a new genre that emerged as a result of artists' creativity from the wealth of folk dance in Priangan, the birth of Jaipongan. This section tells about Gugum Gumbira as the initiator of Jaipongan. And discussing about the change of art from entertainment to show. The problems that occur in this dissertation do not represent the art or folk dance in Priangan, here are only limited to the development of ronggeng, so that many other folk dances are not discussed, because the core of this dissertation is seen as social change from ritual, to entertainment to became a show in the art of ronggeng that appeared clearly. This dissertation has many contributions including, in the art of bangreng, there is also the term ronggeng, so that there are many inputs in discussing Ronggeng, and can see whether it has the similarity between ronggeng and bangreng as discussed in this dissertation. This dissertation discusses the historical art of ronggeng and the dynamics of ronggeng art change both from functions ranging from rituals, entertainment and performances, as well as naming changes from the art of ronggeng to ketuktilu and Jaipongan. While what will be discussed by the author is about the art of bangreng and the life of the community of the art of bangreng which causes this art to survive.

Third, Anis Sujana's book entitled Politics of the Body of Signs and the Meaning of Sinden at the Stage Bajidoran. This book contains Sinden Bajidoran, the name derived from the sinden performances in bajidoran. ${ }^{3}$ The name Sinden is another term of wayang golek in Kliningan which is a refinement of the word ronggeng. In Bajidoran, the name Sinden Bajidoran is raised as a substitute term for Ronggeng. There are two group in the performances, singers and dance interpreters. So in bajidoran there are 10-12 bajidoran sinden, which are divided into Sinden Bajidoran dancers, singers, and some who do both of them. Sinden Bajidoran who served as dancers are usually around 17-30 years old and could be girls and widows, while for sinden bajidor as singers are usually married, the

${ }^{3}$ Anis Sudjana. Politik Tubuh Tanda dan Makna Sinden di Panggung Bajidoran. (Bandung: Sunan Ambu Press, 2015). 
sinden group leaders commonly the wife of the leader. This book also discusses sinden from the comparison of four bajidor groups in Karawang, in terms of costume, and the addition of body curves to the foam carried out by each bajenoran.

In this book, it is explained that the management of the female body of women's entertainment performances in all spaces and at all times has the same pattern. This pattern is reflected in aspects of its formation that are partly natural, some are engineered with types of false signs and lies. In the realm of clothing, it is tightly designed so that the curves and puffs of the body are clearly visible. Sometimes the size is minimal, so that part of the body looks naked. Likewise in a more nimble and erotic movement, and the others discussed are traditional good make up using natural materials until at this time become the most important part for sinden bajidoran. Such as in body management on how to be fit when sitting with a cute face with rancingeus gestures, tangginas, and Someah language. Including discussing body posture, where the upper part must be slender, which is rather contained is referred to as demplon, denok etc., and while for the lower part with the term campernik. The difference between this research and what the writer will do is, in this study only discuss the problems related to sinden bajidoran, while what the writer will do is about bangreng art, which includes the dynamics of social change in the bangreng art community. So that the discussion that is carried out is not only the content of the book, sinden, but what is the social life of nayaga, ronggeng, even the people who enjoy the art of bangreng.

Fourth, the book of Ardawati Durban Ardjo entitled Sundanese Dance Year 19401965 this book contains the development of Sundanese dance from 1940-1965 that emerged from the dance figure Rd. Tjetje Somantri and Tb Oemay Martakusuma, so that folk art is not much discussed in this book. The similarity with the research that will be carried out is that both dance art originating in Sunda, but the difference in this book only discusses the classical Sundanese dance that develops in the masses while bangreng art is a Sundanese art that develops in society or better known as folk art. ${ }^{4}$

Fifth, the Epon Ningrum's Journal entitled Dynamics of Traditional Communities in Kampung Naga in Tasikmalaya Regency this journal contains the

\footnotetext{
${ }^{4}$ Ardjo Irawati Durban. Tari Sunda Tahun 1940-1965. (Bandung: Pusbitari Press, 2008).
} 
dynamics of the people of Naga village who are still contaminated by customs. ${ }^{5}$ However, there has been changes in the dynamics of society in technology, livelihoods, income and ownership of living facilities. The similarity with the research that will be carried out is that both discuss about the dynamics of social change that occur, but the difference is found in the object being studied, in this book discusses the dragon village, while the research will be conducted more on the art of bangreng as a medium of Islamic preaching.

The sixth, Yuyus Rustandi;s Journal entitled jaipongan Influence on bangreng Art is a journal about the influence of jaipongan on bangreng art. The influence of jaipongan in bangreng art can be seen from the changes in dance movements in bangreng performances. The changes occur in the dance movements such as the motions of wave motion, rubber tires, banyu waves, egrets, and gober. Influence in terms of karawitan is the addition of jaipongan musical instruments to the art of bangreng. ${ }^{6}$ The similarity with researcher is that they both discuss the art of bangreng, in this journal explore to the insight of jaipongan writers as one of the factors in the change of Bangreng. The difference of this research, it is focused on the influence of jaipongan on the origins of bangreng art while the research that will be conducted by the researchers discusses in more detail the beginning of bangreng art as a means of Islamic preaching.

None of these theoretical studies show that this study links art with ritual. Where art is one of the products of cultural results carried out by a group of people.

\section{Research Methods}

According to Creswell, there are three types of research that can be presented, namely qualitative, quantitative and mixed methods. ${ }^{7}$ In accordance with what Creswell defined about Qualitative Research as a method for exploring and understanding the meaning. ${ }^{8}$ This research is understanding and exploring the

\footnotetext{
${ }^{5}$ Epon Ningrum. "Dinamika Masyarakat Tradisional Kampung Naga di Kabupaten Tasikmalaya" Mimbar Vol. XXVIII, No. 1 (2012):47-5.

${ }^{6}$ Yuyus Rustandi. "Pengaruh Jaipongan Terhadap Seni Bangreng." Jurnal Wahana Vol 1, No 13 (2017): 14-20.

${ }^{7}$ John W. Creswell. Research Design Pendekatan Kualitatif, Kuantitatif, dan Mixed. (Yogyakarta. Pustaka Pelajar, 2013), 4

${ }^{8}$ Ibid, 3
} 
performance of bangreng art. This is reinforced by the Moleong's opinion that qualitative research requires more guidance in the direction of substantive theory development based on data. ${ }^{9}$

The purpose of this study is to understand a model of preservation of traditional art through the art of bangreng. To be able to explore all the data needed, Creswell discusses five approaches that can be applied in qualitative research including Narrative Study, Phenomenology, Grounded Theory, Ethnography and Case Study. ${ }^{10}$ This research focuses about the descriptions of bangreng art's development in Sumedang Regency, the discussion carried out by researchers in this study is about ritual activities, community behavior and activities concerning the art of bangreng. The approach taken is ethnographic approach. Ethnographic research is meaningful to build a systematic understanding of all human cultures from perspective that have studied culture. Ethnographic case studies involve the use of more specialized observations, participant observations accompanied by unstructured interviews. Ethnographic researchers are deeply involved, better known as observer participants with the aim of understanding the social situation of the places that are used as the object of the study. Observations about society are the biggest part of this approach.

Overall the strength of this research relies on a qualitative paradigm with an ethnographic approach. More emphasis on this qualitative paradigm is caused by several assumptions, including:

The assumptions above shows that for qualitative researchers on ontological questions where reality is a situation created by individuals involved in research, dual reality usually arises. In an epistemological statement the relationships commonly carried out in research usually occur in the form of living together while observing informants within a certain period of time. In an axiological question, researchers report the values that occur in the field. In the rhetorical question, there was the development of language from data sources that had different grammar from researchers. Likewise in methodological questions there will definitely be a research process.

\footnotetext{
${ }^{9}$ Lexy J. Moleong, Metodologi Penelitian Kualitatif. (Bandung, Remaja Rosdakarya, 1994), 3.

${ }^{10}$ John W. Cresswell, Op.Cit, 94
} 
The method will describe the data in the field as an illustration of the dynamics of changes in bangreng art textually and contextually. In an effort to understand the dynamics of the change in bangreng art, direct observations were made to the locations of regions that had bangreng art and the dynamics of the change in bangreng art could be carried out through structuralism and semiotic theories. Structural theory sees cultural symptoms as a structure while semiotic theory sees culture as a sign system. ${ }^{11}$

The steps taken are through (1) direct observation to the field of the origin of the traditional art tradition; (2) the form and structure of the performance of bangreng art; (3) the dynamics of changes in bangreng art textually and contextually from time to time; (4) the connection between the change in the art of bangreng and the life of the community supporting the art of bangreng in Situraja.

\section{Data Types}

Data collected through qualitative data, both primary and secondary data. In the process of completing the qualitative data, the relevant quantitative data types are collected with various other data that can support the explanation of qualitative data.

Qualitative data used in the study prioritize the form of 'what', 'why', and 'how' questions which are then explained as carefully as possible in an effort to obtain quality results. Strength in this research is interpreting, understanding, interpreting, and analyzing to get optimal research results on the dynamic changes in bangreng art textually and contextually in the Situraja Sumedang Community.

\section{Data Collection Techniques}

The essence of a research is looking for data that will be interpreted and analyzed. The data needed in this study are primary data and secondary data. Primary data is information data originating directly from the resource person in the form of words and actions, while secondary data is data in the form of documents from various sources, agencies, related sources and independent researchers. Primary data was obtained from Situraja community members who were often involved in the art of bangreng either as actors, spectators and traders from a long time ago. Secondary data

\footnotetext{
${ }^{11}$ Sulasman and Setia Gumilar. Teori-teori Kebudayaan. (Bandung: Pustaka Setia, 2013), 96.
} 
is obtained through the village office or government offices related to the topics discussed, as well as from the results of previous researchers.

Data collection techniques in this study were divided into three ways, namely observation, interviews, and document study.

Observation

One of the data collection techniques that researchers use in reviewing the dynamics of social change in bangreng art in Sumedang Regency is to use observation. This observation activity was carried out to make observations of all people involved in bangreng art activities, both players, spectators, and traders involved in the art of bangreng. In this activity researchers conducted observations of community actions and behaviors, as well as social interactions carried out from various roles in the performance of bangreng arts. In this observation the researcher was also involved as an observer participant.

Interview

Data regarding offerings in bangreng, sinden or ronggeng art performances and saweran culture in bangreng art and others cannot be explored only by observation. There should be another technique to complete and enrich the findings in the study, in that case interviews need to be done. The purpose of the interview was to find out what was contained in the mind and heart of the interviewee. In this study interviews will be conducted in several groups including the leaders of the bangreng art group, the artists involved, the owners of the riots and the figures involved in the art of bangreng.

Document Study

In qualitative studies, document studies cannot be abandoned, because they are very helpful in completing data and checking the truth. The documentation study referred to in qualitative research is generally a technique that is carried out through the collection of written documents, for example personal records, reports, correspondence, agendas, or other records which are evidence of the implementation of a process or activity that has occurred. In this study, documents that will be collected in the form of personal notes, audio, audio visual and other data owned by the community owners and actors of the arts in Situraja, Sumedang Regency 


\section{Research Data Analysis}

In data analysis, data will be presented in a form that is easy to read, understand and interpret. Data analysis aims to obtain answers to the research problems that have been proposed. Data analysis is carried out based on the approach and type of research used. Descriptive data obtained is then processed qualitatively. This data analysis can be done through data reduction, data presentation and conclusion drawing that was previously carried out by data collection and data verification.

The data analysis plan that will be carried out is by processing qualitative data. After the data has been collected, either in the form of notes, records or other forms, the data is revealed in detail. The researcher tries to analyze the data with the following steps:

a. Classify each theme, according to the pattern of data from the results of the study.

b. Adjust and compare data between field results and literature in the form of theory and resource persons to support a number of conclusions.

c. Describe the results of research that has undergone a process of processing.

d. Analyze data based on research problems.

Data analysis activities that will be carried out by researchers are through raw data descriptions, reduction and triangulation. Data description activities are important to know data that has been successfully collected during research activities. After describing existing data, the next process is to reduce existing data. By reducing this data, it is hoped that it will get an overview of important data that is related and needed in research. Meanwhile triangulation is needed to compare data from interviews with several informants, observations, and literature studies. Then the researcher will do data grouping based on the focus of the study. To get a picture of getting a clear and in-depth picture, the researchers conducted data validation and verification activities.

Bangreng Art as a Means of Spreading IslamFlying is an art that is related to ritual ceremonies usually used in the ceremony. The musical instrument used uses three pieces of gemyung, kendang, goong from bamboo. The lyrics of the song are about religious songs, such as saying "La ilaha illa Allah Muhammadurrasulullah" done 
repeatedly. Men did the singing at the time of the flying performance. With a simple music motif, it is always repeated. In this flying show, it is only done on the show. This inheritance system in flying art is not done arbitrarily but is inherited from generation to generation. Even so, until now the art of flying is still well maintained.

This flying show is a ritual performance, because it has always repetitive characteristics both music and music in one song. The duration in one song is very diverse and relatively long. This activity can be said to be the spread of Islam because the song that is sung is a rumpaka, which is related to Islam such as "La ilaha illa Allah Muhammadurrasulullah" and in a gesture of the majesty of Allah SWT and the prophet Muhammad.

Flying shows, they are dancers, usually the dancing guests do the twisting. While reading the prayers sung by musicians. His mother has been there since the beginning of the flight, it was only danced by men. The dance is always circling and going around.

From the dance and flying music, we can see that this is the art that spread Islam at that time, because it shows the nuances of Islamic teachings as practiced by Muslims when performing the pilgrimage which must carry out tawaf. Traveling around and repetitive music while backing shalawat shows the ritual position like tawaf in Mecca.

\section{Conclusion}

That this flying show is a form of Islamic religious rituals in which this performance in bangreng art shows the spiritual existence between dancers and the creator through flying art media

\section{References}

A Teeuw. Sastera dan Ilmu Sastera. Bandung: Pustaka Jaya, 2003.

Anis Sudjana. Politik Tubuh Tanda dan Makna Sinden di Panggung Bajidoran. Bandung: Sunan Ambu Press, 2015.

Baker Chris. Cultural Studies Teori dan Praktik. Yogyakarta: Bentang, 2000.

Bourdieu, Pierre. Outline of Theory of Practice. Cambridge: Polity Press, 1977.

Burke, Peter. Sejarah dan Teori Sosial. Jakarta: Yayasan Pustaka Obor Indonesia, 2015. 
Caturwati, Endang. "Sinden - Penari di atas dan di luar Panggung :Kehidupan Sosial Sosial Budaya para Sinden-Penari kliningan Jaipongan di Wilayah Subang Jawa Barat”. Disertasi, UGM, 2005. .. Sinden - Penari di Atas di Luar Panggung. Bandung: Sunan Ambu Press 2011.

Creswell, John W. Research Design Pendekatan Kualitatif, Kuantitatif, dan Mixed. Yogyakarta: Pustaka Pelajar, 2013. . Peneltian Kualitatif dan Desain Riset. Yogyakarta: Pustaka Pelajar, 2014.

Danandjaja, James.Foklor. Jakarta: Grafiti Utama Press, 2008.

David, Kaplan and Robert A., Manners. Teori Budaya. Yogyakarta: Pustaka Pelajar, 2002.

Dayaksini Tri and Saslis, Yuniardi. Psikologi Lintas Budaya. Malang: UMM Press, 2012.

Durban, Ardjo Irawati. Tari Sunda Tahun 1940-1965. Bandung: Pusbitari Press, 2008.

Dwi, Susanto. Pengantar Teori Sastra. Jakarta: CAPS, 2012.

Fatimah, Djajasudarma $\mathrm{T}$ and Elvi, Citraresmana. Metodologi dan Strategi Penelitian Linguistik. Bandung. Universitas Padjadjaran, 2016.

Herdiani, Een. "Dinamika Tari Rakyat di Priangan”. Disertasi, Universitas Padjadjaran, 2012.

. Dinamika Tari Rakyat di Priangan. Bandung: Sunan Ambu Press, 2014.

Jaeni. Metode Penelitian Seni. Bandung: Sunan Ambu Press, 2015.

Kajian Seni Pertunjukan. Bandung: STSI Press, 2011.

. Komunikasi Estetik. Bogor: IPB Press, 2012.

Kuhn, Thomas S. The Structure of Scientific Revolutions: Peran Paradigma dalam Revolusi Sains. Bandung. PT Remaja Rosdakarya Offset, 2012.

Kuper, Adam and Jesika. Enslikopedi Ilmu-Ilmu Sosial. Terjemahan. Jakarta: Raja Grafindo Perkasa, 2000.

Magetsari, Noerhadi. Krisis Identitas, Dalam Krisis Budaya. Jakarta: Pustaka Obor Indonesia, 2016.

Makin Al. Keragamandan Perbedaan: Budaya dan Agama dalam Lintas Sejarah Manusia. Yogyakarta: Suka Press, 2016.

Merriam, Alan P. The Antropology of Music. United State Of America: University Press, 1964.

Moleong, Lexy J., Metodologi Penelitian Kualitatif. Bandung: Remaja Rosdakarya, 1994.

Ningrum, Epon. "Dinamika Masyarakat Tradisional Kampung Naga di Kabupaten Tasikmalaya" Mimbar Vol.XXVIII, No 1 2012: pp. 47-54

Riyadi, Slamet. "Alan P Merriam Versus Mantle Hood dalam Orientasi Studi Etnomusikologi”. Jurnal Ilmiah Keteg Gendhing Vol 2 No 1 Mei 2002: 101-114 
Jurnal Hunafa: Studia Islamika, Volume 16, Number 1, p. 19-32.

Rustandi, Yuyus.“Pengaruh Jaipongan Terhadap Seni Bangreng” Jurnal Wahana Vol 1, No 13 2017: pp. 14-20.

Smiersjoost. Art Under Pressure. Yogyakarta: Insist Pressori, 2009.

Soemardjan, Selo. Perubahan Sosial. Yogyakarta: Gadjah Mada University, 1991.

Sulasman and Gumilar, Setia. Teori-teori Kebudayaan. Bandung: Pustaka Setia, 2013. 